\title{
The Institutional Benefits of Mentoring
}

\author{
Melanie Thorley \\ *AccessAbility Project Co-ordinator, Access \& Widening Participation Unit
}

The concept of mentoring is by no means a modern idea. Homer's Odysseus entrusted his friend, Mentor, to nurture and educate his son whilst he was fighting Trojans over 3,000 years ago.

Traditionally, mentoring within an educational environment has been used as a tool to address the inequity faced by many under-represented, as noted by De Janasz et al. (2008). Today, mentoring can have a positive impact on mentors, mentees and the institution involved. Recent research by Barnett (2008) has suggested the following:

"Benefits to institutions potentially include more satisfied faculty and students with lower rates of attrition ... greater scholarly productivity ... enhanced prestige for the institution, more committed alumni, and the likelihood of having more mentors in the future."

The University of Greenwich has provided various mentoring services for a number of years in different faculties and departments, especially within the Access \& Widening Participation Unit (AWPU) and the Office for Student Affairs. Successful, positive mentoring programmes can also enable different departments to work together. For example, Aspire (SE London Aimhigher), AWPU and the Diversity Office are currently working together to provide a mentoring scheme for careleavers, a cohort which continues to be very under-represented within higher education.

Mentoring can improve networking skills which in turn can benefit the institution. De Janasz et al. (o.c.), note that mentees who are involved in an effective mentoring relationship can often increase their academic performance, which can also impact on the number of higher class degrees awarded within a particular higher education institution. The Mentoring and Befriending Foundation (MBF) suggests that trust, confidentiality and mutual involvement are key components to successful mentoring. The philosophy of peer mentoring at the University of Greenwich echoes the sentiments of the MBF, with emphasis on enthusiasm, motivation and support (Bartoli 2008). Gormley (2008) identifies the impact that mentoring can have on retention - providing psychosocial support for mentees - means that students are less likely to drop out of university. My own experience also shows that student mentors are less likely to abandon their studies as they are in a position of responsibility, yet another reason to embrace successful mentoring projects. 


\section{References}

Barnett, J. (2008). Mentoring, boundaries and multiple relationships: opportunities and challenges.

Mentoring \& Tutoring: Partnership in Learning, Vol. 16, No 1.

Bartoli, M. (2008). Peer mentoring training. University of Greenwich.

De Janasz, S.C., Ensher, E. A., and Heun, C. (2008). Virtual relationships and real benefits: using e-mentoring to connect business students with practicing managers. Mentoring \& Tutoring: Partnership in Learning, Vol. 16, No 4.

Gormley, B. (2008). An application of attachment theory: mentoring relationship dynamics and ethical concerns. Mentoring \& Tutoring: Partnership in Learning, Vol. 16, No 1.

Mentoring and Befriending Foundation. What is mentoring and befriending. [Online]. Available at: http://mandbf.org.uk (accessed 8 June 2009). 